\title{
Relationship of Work in Pandemic Era with Increased Risk of Musculosceletal Disorders that Lead to Change in Cervical Posture
}

\author{
Dea Linia Romadhoni, Alinda Nur Ramadhani, Exda Hanung Lidiana \\ Universitas ‘Aisyiyah Surakarta, Surakarta, Central Java
}

\section{ABSTRACT}

Background: Musculoskeletal Disorders (MSDs) was a form of complaints that occur in muscles, bones, joints, ligaments and tendons. Globally, musculoskeletal disorders were the single largest cause of work-related health complaints with more than $33 \%$ of all new diseases reported. Risk factors that contribute to caused MSDs were social factors. This study aimed to analyze the relationship between social factors related to the risk of MSDs and their effect on changes in cervical posture.

Subjects dan Method: This was a cross-sectional study. A sample of 32 were selected for this study with. The sampling technique used was total sampling according to the inclusion and exclusion criteria. This study was conducted online through the google-form application by respondents in Surakarta, Central Java from March 2021 to May 2021. The dependent variable was changes in cervical posture. The independent variable was the respondent's characteristics such as work environment and work posture. The data analysis technique used Chi Square test.

Results: The results of the analysis using the Chi Square test showed that there was a relationship between work duration and work risk factors with $\mathrm{OR}=9.00 ; 95 \% \mathrm{CI}=1.72$ to $46.9 ; \mathrm{p}=0.010$. Based on these results, it can be interpreted that workers with working duration $>7$ hours per day are 9 times more likely to have a high risk injury risk factor compared to workers who work $<7$ hours a day. The results of the analysis with the Chi Square test showed that there was a relationship between risk factors for injury and a high risk work environment with forward head posture with $\mathrm{OR}=20.00 ; 95 \% \mathrm{CI}=2.11$ to $189 ; \mathrm{p}=0.003$ ). Workers with risk factors for injury and a high risk work environment are 20 times more likely to experience forward head posture compared to workers with risk factors for injury and a risky work environment.

Conclusion: There is a relationship between duration of work with work risk factors, there is a relationship between environmental factors and risk factors for injury and there is a relationship between risk factors for injury and a high-risk work environment with forward head posture.

Keywords: pandemic era, musculosceletal disorders, cervical posture change.

\section{Correspondence:}

Dea Linia Romadhoni. Universitas 'Aisyiyah Surakarta, Jl. Ki Hajar Dewantara 10, Surakarta 57146, Central java, Indonesia. Email: dealiniafisio@gmail.com.

\section{Cite this as:}

Romadhoni DL, Ramadhani AN, Lidiana EH (2021). Relationship of Work in Pandemic Era with Increased Risk of Musculosceletal Disorders that Lead to Change in Cervical Posture. J Epidemiol Public Health. 06(03): 347-354. https://doi.org/10.26911/jepublichealth.2021.06.03.08

(c) (1) Journal of Epidemiology and Public Health is licensed under a Creative Commons Attribution-NonCommercial-ShareAlike 4.0 International License.

\section{BACKGROUND}

Musculoskeletal Disorders (MSDs) is a form of complaints that occur in muscles, bones, joints, ligaments and tendons.
Globally, musculoskeletal disorders are the single largest cause of work-related health complaints with more than $33 \%$ of all new diseases reported (Bodhare et al., 2011). 
Complaints of MSDs are also found in countries with high industrial rates and are the biggest cause of absenteeism due to illness. Research conducted in Saudi Arabia, at least $13 \%$ of workers absent, $22 \%$ had to reduce working hours related to their work and $46 \%$ had to take regular medication (Iqbal and Alghadir, 2015) this is in line with research in Hong Kong in 2016, around $39.2 \%$ of workers suffered from musculoskeletal pain (Yi and Chan, 2016). In Indonesia, there are $62.5 \%$ of all workers complaining of low musculoskeletal disorders and $37.5 \%$ of workers complaining of high musculoskeletal disorders (Tofan et al., 2017). The impact of musculoskeletal disorders is can affect productivity and if maintained for a long time can affect changes in body posture such as forward head posture (FHP), scoliosis, kyphosis, lordosis, and thorticollis. Change in body posture caused by MSDs have a significant impact on finance and quality of life, often patients who are referred with cervical MSDs complaints are accompanied by FHP because it is directly connected to the spine, FHP can be caused by social factors related to work (Gray et al., 2020).

According to WHO (2009), the risk factors that contribute to cases of MSDs are social factors. Social factors include the type of work, work posture and work environtment. Type of wirk affects how high the risk of MSDs is, where workers with excessive physical activity are $76.2 \%$ at risk of developing MSDs (Yi and Chan., 2016), an unergonomic work environment will increase the risk of MSDs by 20\% and another study stated that a bad work environment increased 34.4\% (Tofan et al., 2017), and non-ergonomic work postures with a sedentary body position for several hours could increase MSDs by $62.8 \%$ (Chinyere, 2014).
Based on the description above, many workers complain of pain in the cervical area, especially during the current pandemic where workers, especially office workers are required to work both offline and online for long periods of time and use computer/laptop without paying attention to the ergonomic position when working. This will have a serious impact on work, productivity and well-being. Researchers have conducted a preliminary study on several office workers who work using computers/laptops and the results obtained that approximately $45 \%$ of workers complain of MSDs, so this study aimed to know the relationship between social factors related to the risk of MSDs and their effect on changes in cervical posture.

\section{SUBJECTS AND METHOD}

\section{Study Design}

This was a cross-sectional study. It was conducted on office workers in Surakarta from March to May 2021.

\section{Population and Sample}

The population in this study were office workers in Surakarta. The subjects of this study were office workers with online and offline jobs. The sampling technique used was total sampling according to the inclusion and exclusion criteria. Inclusion criteria: office worker/employee, 25-55 years old, work online or offline during covid-19 pandemic, work using laptop, computer, tablet or handphone and complaining of neck pain when working. Exclusion criteria: have a history of cervical fracture, have a spinal deformity (kyphosis), have a congenital spinal deformity and working with high mobility. There were 36 people who filled out the informed consent, 4 people included the exclusion criteria and a total of 32 people became the research subjects. 


\section{Study Variables}

The dependent variable was changes in cervical posture. The independent variable was the respondent's characteristics such as work environment and work posture.

\section{Operational Definition of Variables}

Dependent variabel consist of work environment and work posture, while the independent variable in this study is forward head posture. Work environment defined as all that is around the workplace that can affect the research subject either directly or indirectly, as well as form of activities carried out by the subject. Work environment factors were measured using the PLIBEL checklist with continuous data scale. Work environment factors were measured using the PLIBEL checklist with continuous data scale. The measurement results with PLIBEL are then categorized into at risk and high-risk work environment. Work posture is defined as the state of a person's body, body shape and posture when doing a job that can be measured using the posture assesment method. Measurement of work posture using REBA (Rapid entire Body Assessment) which is then categorized into risky work posture and high-risk work posture. Forward head posture assessment using craniovertebral angle measurement. The assesment is carried out by observing the photo of the work position attached to the google form by the subject. The observations are categorized into forward head posture and not (normal).

\section{Study Instruments}

Data collection techniques are carried out online using a google form by attaching research instruments and informed consent. Work environment risk factors were measured using the PLIBEL checklist in- strument. The measurement results are categorized into risky and high risk work environments. Working posture was measured using the REBA instrument. The measurement results are categorized into low risk, medium risk, high risk and very high risk. Changes in cervical posture (forward head posture) were measured using a cariovertebral angle measurement. The measurement results are categorized into forward head posture or normal.

\section{Data analysis}

The data analysis technique used univariate analysis and bivariate analysis. Univariate analysis is an analysis conducted to describe the character of the study subject and the characteristics of each research variable in the form of a frequency distribution table. The statistical test used in this study is the chi square test to see the significance of statistical calculations using a significant level of $5 \%$ and from the results of bivariate analysis on research variables that have $\mathrm{p}<0.25$.

\section{Research Ethics}

The research ethical clearance approval letter was obtained from Research Ethics Committee of 'Aisyiyah University Surakarta, Indonesia, Number: oo8/VIII/AUEC /2021.

\section{RESULTS}

\section{Sample Characteristics}

The research subjects were 32 people with an age range of 25-55 $\mathrm{s}$ who worked in an office using gadgets such as laptops, cellphones, computers and tablets. The results of the study describe the characteristics of the research subjects including gender, work method and type of work. Characteristics of research subjects can be seen in the following table: 
Romadhoni et al./ Musculosceletal Disorders and Cervical Posture during COVID-19 Pandemic

Table 1. Characteristics of Subjects

\begin{tabular}{llcc}
\hline Characteristics & Category & Frequency & Percentage \\
\hline Gender & Female & 21 & 65.6 \\
Work Method & Male & 11 & 34.4 \\
& Offline & 5 & 15.6 \\
& Online & 3 & 9.4 \\
\multirow{3}{*}{ Type of Work } & Offline and Online & 24 & 75 \\
& Office Worker & 16 & 50 \\
& Lecturer, teaching assistant and teacher & 14 & 43.8 \\
& Government employee & 2 & 6.2 \\
\hline
\end{tabular}

Table 1 shows that the research subjects were 21 women (65.6\%) and 11 men (34.4\%). Research subjects who work using offline methods are 5 people (15.6\%), online are 3 people $(9.4 \%)$ and offline and online are 24 people (75\%). Research subjects who work using offline methods are 5 people (15.6\%), online are 3 people (9.4\%) and offline and online are 24 people (75\%).

\section{Univariate Analysis}

Research variables include independent variables (work environment and work posture) and dependent (forward head posture). Table 2 shows that of the 32 research subjects who worked $<7$ hours per day as many as 14 people (43.8\%) and $>7$ hours as many as 18 people (56.3\%). Subjects who have risk factors for injury are at risk as many as 12 people (37.5\%) and very at risk as many as 20 people (62.5\%). Subjects with work environment at risk were 18 people (56.3\%) and very at risk were 14 people (43.8\%). Subjects with forward head posture were 21 people (65.6\%) and those without forward head posture were 11 people (34.4\%).

Table 2. Univariate Analysis of Independent Variables and Dependent Variables

\begin{tabular}{llcc}
\hline \multicolumn{1}{c}{ Characteristics } & \multicolumn{1}{c}{ Category } & Frequency & Percentage \\
\hline Work Duration & $<7$ hours & 14 & 43.8 \\
& $>7$ hours & 18 & 56.3 \\
Injury Risk Factors & At risk $(<47 \%)$ & 12 & 37.5 \\
\multirow{2}{*}{ Risky Work Environment Factors } & High risk $(>47 \%)$ & 20 & 62.5 \\
& At risk $(<31 \%)$ & 18 & 56.3 \\
Forward Head Posture & High risk $(>31 \%)$ & 14 & 43.8 \\
& No & 11 & 34.4 \\
& Yes & 21 & 65.6 \\
\hline
\end{tabular}

\section{Bivariate Analysis}

Bivariate analysis is used to see the relationship between the independent variable and the dependent variable. Bivariate analysis was performed using the chi-square test and calculated odds ratio (OR) with a 95\% confidence level (CI). The results of the bivariate analysis can be seen in the following table: 
Romadhoni et al./ Musculosceletal Disorders and Cervical Posture during COVID-19 Pandemic

Table 3. Bivariate Analysis of the Relationship of Independent Variables with Injury Risk Factors in Workers

\begin{tabular}{|c|c|c|c|c|c|c|c|c|}
\hline \multirow{2}{*}{$\begin{array}{l}\text { Independent } \\
\text { Variables }\end{array}$} & \multicolumn{2}{|c|}{$\begin{array}{c}\text { Low Risk of } \\
\text { Injury }(<47 \%)\end{array}$} & \multicolumn{2}{|c|}{$\begin{array}{c}\text { High Risk } \\
\text { Injury }(>47 \%) \\
\end{array}$} & \multirow{2}{*}{ OR } & \multicolumn{2}{|c|}{$95 \% \mathrm{CI}$} & \multirow{2}{*}{$\mathbf{p}$} \\
\hline & $\mathbf{n}$ & $\%$ & $\mathbf{n}$ & $\%$ & & $\begin{array}{c}\text { Lower } \\
\text { limit }\end{array}$ & $\begin{array}{l}\text { Upper } \\
\text { Limit }\end{array}$ & \\
\hline $\begin{array}{l}\text { Work } \\
\text { duration }\end{array}$ & 9 & 64.2 & 5 & 35.8 & 9.00 & 1.72 & 46.9 & 0.010 \\
\hline $\begin{array}{l}<7 \text { hours } \\
>7 \text { hours } \\
\text { Risky work } \\
\text { environment } \\
\text { At risk }(<31 \%)\end{array}$ & 3 & 16.7 & 15 & 83.3 & & & & \\
\hline $\begin{array}{l}\text { High-risk } \\
(>31 \%)\end{array}$ & $\begin{array}{c}10 \\
2\end{array}$ & $\begin{array}{c}55 \cdot 5 \\
14\end{array}$ & $\begin{array}{c}8 \\
12\end{array}$ & $\begin{array}{c}44.5 \\
86\end{array}$ & 7.50 & 1.28 & 43.6 & 0.028 \\
\hline
\end{tabular}

Based on table 4.3, the results of the bivariate analysis of work duration variable show that workers who have the highest risk of injury risk factors are workers who work $>7$ hours per day as many as 15 people (83.3\%). Workers who have risk factors for risk of injury are workers who work $<7$ hours per day as many as 9 people (64.2\%). The results of the analysis using the Chi Square test showed that there was a relationship between work duration and work risk factors and $(\mathrm{OR}=9.00 ; 95 \% \mathrm{CI}=1.72$ to 46.9; $\mathrm{p}=0.010)$. The results of the analysis using the Chi Square test showed that there was a relationship between work duration and work risk factors and $(\mathrm{OR}=9.00 ; 95 \%$ $\mathrm{CI}=1.72$ to $46.9 ; \mathrm{p}=0.010)$. Based on these results, it can be interpreted that workers with working duration $>7$ hours per day are 9 times more likely to have a very risky injury risk factor compared to workers who work $<7$ hours a day.

The results of the bivariate analysis of risky work environment factors indicate that workers who have the highest risk of injury are at risk, namely workers who work in a very risky work environment as many as 12 people (86\%). A total of 10 people (55.5\%) workers who have risk factors for risk of injury are workers who work in a risky work environment. The results of the analysis using the Chi Square test showed that there was a relationship between environmental factors and risk factors for injury and $(\mathrm{OR}=7.50 ; 95 \% \mathrm{CI}=1.28$ to $43.6 ; \mathrm{p}=$ 0.028). Based on these results, it can be interpreted that workers with very risky work environment factors have a 7.5 times greater likelihood of having a very risky injury risk compared to workers in a highrisk work environment.

Table 4. Bivariate Analysis of the Relationship between Injury Risk and Work Environment Variables with Forward Head Posture in Workers

\begin{tabular}{|c|c|c|c|c|c|c|c|c|}
\hline \multirow[t]{2}{*}{ Variables } & \multicolumn{2}{|c|}{ Non FHP } & \multicolumn{2}{|c|}{ FHP } & \multirow[b]{2}{*}{ OR } & \multicolumn{2}{|c|}{$95 \% \mathrm{CI}$} & \multirow[b]{2}{*}{$\mathbf{p}$} \\
\hline & $\mathbf{n}$ & $\%$ & $\mathbf{n}$ & $\%$ & & $\begin{array}{l}\text { Lower } \\
\text { limit }\end{array}$ & $\begin{array}{l}\text { Upper } \\
\text { limit }\end{array}$ & \\
\hline PLIBEL & & & & & & & & \\
\hline At risk $(<79 \%)$ & 10 & 58.8 & 7 & 41.2 & 20.00 & 2.11 & 189.00 & 0.003 \\
\hline High-risk (>79\%) & 1 & 6.7 & 14 & 93.3 & & & & \\
\hline
\end{tabular}


Based on table 4, the results of the bivariate analysis of injury risk factors and work environment with forward head posture indicated that workers with injury risk factors and high-risk work environment that experience forward head posture as many as 14 people (93.3\%). Workers who have injury risk factors and a risky work environment who experience forward head posture are 10 people $(58.8 \%)$. The results of the Chi-Square test showed that there was a relationship between risk factors for injury and high-risk work environment with forward head posture and $(\mathrm{OR}=$ 20.00; 95\% $\mathrm{CI}=2.11$ to $189.00 ; \mathrm{p}=0.003$ ). Workers with risk factors for injury and high-risk work environment are 20 times more likely to experience a forward head posture compared to workers with risk factors for injury and a risky work environment.

\section{DISCUSSION}

Non-ergonomic work environment is associated with the risk of MSDs in workers. Non-ergonomic work environment can cause non-ergonomic work posture that are associated with MSDS complaints (Romadhoni and Ramadhani, 2021). Work environment condition, especially chair height, armrest, and backrest are associated with non-ergonomic upper extremity work posture and these factor can caused musculoskeletal pain in office workers who use computer(Rodrigues et al., 2017). In line with the study of (Nejati et al., 2015) that neck pain is associated with poor cervical and thoracic vertebral posture at work. Office workers with complaints of neck pain have poor work posture when working with computers in a forward looking sitting position. This is related to the position of chair, desk and computer that are not appropriate (ergonomic) and a lack of attention or awareness of body position while working.

Non-ergonomic work position can increase the risk of MSDs in workers, especially in the upper and lower extremities (Ansari and Sheikh, 2014; Mohammadipour et al., 2018; Romadhoni and Ramadhani, 2021). Head position aginst the monitor screen affects the MSDS complaints in office workers. Head position where the workers look at the computer screen is low, resulting in excessive cervical flexion for a long time. In some workplaces that do not have a suitable document storage area, workers often flex and rotate their neck to retrieve and analyze documents located on the side of the workbench. This position is related to MSDS complaints in the neck. A work environment with a chair without a backrest creates a trunk flexion position while working which can increase the activity of the paravertebrae muscles and static position for a long time resulting in (Ansari and Sheikh, 2014; Kim and Yoo, 2015; Mohammadipour et al., 2018).

Changes in head position can increase the load on the musculoskeletal system. Forward head posture occurs because of the position of lower cervical flexion and upper cervical extension related to the round shoulder position which is included in posture dysfunction. Forward head posture increases upper trapezius and cervical erector spinae muscle activity (Lee et al., 2017). Forward head posture and round shoulders anterior to the line of gravity increase the compressive load on the cervical and thoracic articulations and result in an exaggerated soft tissue response (Kim and Yoo, 2015; Seulgi Lee et al., 2017). It is clinically known that the superficial muscles (eg: upper trapezius) in the posterior part become overactive and tense, while the deep muscles in the front (cervical 
flexor) weaken. Forward head posture and stiffness in the upper trapezius muscles cause neck pain in workers (Moris et al, 2015; Kim and Yoo, 2015; Kocur et al., 2019). Setting the distance from the front of the workbench from the body and the angle of the shoulders and head forward when doing work need to be considered to prevent changes in posture and pain in the neck and shoulders of workers (Kim and Yoo, 2015).

This study concluded that there is a relationship between risk factors for injury and a high-risk work environment with forward head posture.

\section{FUNDING AND SPONSORSHIP}

This study was supported by Universitas 'Aisyiyah Surakarta.

\section{ACKNOWLEDGEMENT}

We are very grateful to Universitas 'Aisyiyah Surakarta for the financial support.

\section{CONFLICT OF INTEREST}

There are no conflicts of interest in this study.

\section{REFERENCE}

Bodhare T, Valsangkar S, Bele S (2011). An epidemiological study of work-related musculoskeletal disorders among construction workers in Karimnagar, Andhra Pradesh. Indian $\mathrm{J}$ Community Med. 36(4): 304-307. doi: 10.4103/0970-0218.91420.

Chinyere NI (2014). Influence of workstation and work posture ergonomics on job satisfaction of librarians in the federal and state University Libraries in Southern Nigeria. Int. j. humanit. soc. sci. 19(9): 78-84. doi: 10.9790/o837-19947884.

Gray K, Dalal R, Weaver JD, Randolp S
(2020). Quantitative measurements of forward head in college-aged students: a conformational study of intra-rater and inter-rater reliability of a novel posture measuring device. J Bodyw Mov Ther. doi: 10.1016/j.jbmt.2020.12.008.

Iqbal Z, Alghadir A (2015). Prevalence of work-related musculoskeletal disorders among physical therapists. Med. Pr. 66(4): 459-469. doi: 10.13075/mp.5893.00142.

Khayatzadeh S, Kalmanson OA, Schuit D, Havey RM, Voronov LI, Ghanayem AJ, Patwardhan AG (2017). Cervical spine muscle-tendon unit length differences between neutral and forward head postures: biomechanical study using human cadaveric specimens 'original research. Phys Ther. 97(7): 756-766. doi: $10.1093 / \mathrm{ptj} / \mathrm{pzx} 040$.

Kim MH, Yoo WG (2015). Effect of a worktable position on head and shoulder posture and shoulder muscles in manual material handling. Work. 51(2): 289-292. doi: 10.3233/WOR141866.

Kocur P, Wilski M, Lewandowski J, Łochyński D (2019). Female office workers with moderate neck pain have increased anterior positioning of the cervical spine and stiffness of upper trapezius myofascial tissue in sitting posture. PM R. 11(5): 476-482. doi: 10.1016/j.pmrj.2018.07.002.

Kocur P, Wilski, Maciej, Goliwas M, Lewandowski J, Łochyński D (2019). Influence of forward head posture on myotonometric measurements of superficial neck muscle tone, elasticity, and stiffness in asymptomatic individuals with sedentary jobs. J Manipulative Physiol Ther. 42(3): 195-202. doi: 10.1016/j.jmpt.2019.02.005.

Lee S, Choi YH, Kim J (2017). Effects of the 
cervical flexion angle during smartphone use on muscle fatigue and pain in the cervical erector spinae and upper trapezius in normal adults in their 20s. J. Phys. Ther. Sci. 29(5): 921-923. doi: 10.1589/jpts.29.921.

Lee S, Lee, Y, Chung Y (2017). Effect of changes in head postures during use of laptops on muscle activity of the neck and trunk. Phys. Ther. 6(1): 33-38. doi: 10.14474/ptrs.2017.6.1.33.

Mohammadipour F, Pourranjbar M, Naderi S, Rafie F (2018). Work-related musculoskeletal disorders in iranian office workers: prevalence and risk factors. $\mathrm{J}$ Med Life. 11(4): 328-333. doi: 10.25122/jml-2018-0054.

Morris CE, Bonnefin D, Darville C (2015). The torsional upper crossed syndrome: A multi-planar update to Janda's model, with a case series introduction of the mid-pectoral fascial lesion as an associated etiological factor. J Bodyw Mov Ther. 19(4): 681-689. doi: 10.1016/j.jbmt.2015.08.008.

Nejati P, Lotfian S, Moezy A, Nejati M (2015). The study of correlation between forward head posture and neck pain in Iranian office workers. J Occup Med Environ Health. 28(2). doi: 10.13075/ijomeh.1896.00352.

Patwardhan AG, Havey RM, Khayatzadeh S, Muriuki MG, Voronov LI. Carandang G, Nguyen N, et al. (2015). Postural consequences of cervical sagittal imbalance: A novel laboratory model. Spine. 40(11): 783-792. doi: 10.1097/BRS.0000000000000877.

Prasetya T, Rosanti E, Rahma R (2017). Analysis of factors causing musculoskeletal disorders using rula (rapid upper limb assessment) method in computer operators. Int. J. Appl. Environ. 12(2): 323-340.

Rodrigues MSA, Leite RDV, Lelis CM,
Chaves TC (2017). Differences in ergonomic and workstation factors between computer office workers with and without reported musculoskeletal pain. Work. 57(4): 563-572. doi: 10.3233/WOR-172582.

Romadhoni DL, Ramadhani AN (2021). Association between psychosocial factor and risk of musculosceletal disorders in productive age patient at RSUD Dr. Moewardi Surakarta. Gaster. 19(1): 10. doi: 10.30787/gaster.v19i1.661.

Yi W, Chan A (2016). Health profile of construction workers in Hong Kong. Int. J. Environ. Res. 13(12). doi: 10.3390/ijerph13121232.

WHO (2020). Coronavirus Disease (COVID-19) Situation Reports.

World Population Growth - Our World in Data, n.d. Retrieved from https://ourworldindata.org/world-populationgrowth.

World Bank Open Data|Data, n.d. Retrieved from https://data.worldbank.org/.

You H, Wu X, Guo X (2020). Distribution of covid-19 morbidity rate in association with social and economic factors in wuhan, china: Implications for urban development. Int. J. Environ. Res. Public Health 17 (10): 3417. doi: 10.3390/ijerph17103417.

Zhou F, Yu T, Du R, Fan G, Liu Y, Liu Z, Xiang J, et al (2020). Clinical course and risk factors for mortality of adult inpatients with COVID-19 in Wuhan, China: a retrospective cohort study. Lancet 395(10229):1054-1062. doi: 10.1016/So140-6736(20)30566-3. 